International Journal of Multi Disipline Science (IJ-MDS)

e-ISSN: 2615-1707 DOI: http://dx.doi.org/10.26737/ij-mds.v1i1.425

International Journal of Multi Disipline Science (IJ-MDS) is licensed under

a Creative Commons Attribution-NonCommercial 4.0 International License

\title{
The Effectiveness of Four Corners Strategy in Teaching Writing Hortatory Exposition Text
}

\author{
Monitha Geraldine \\ STBA Pontianak \\ geraldinecassiopeia@gmail.com
}

\section{Keywords: \\ Four Corners Strategy, Writing, Hortatory Exposition Text}

\begin{abstract}
This research investigated the use of Four Corners Strategy in teaching writing hortatory exposition text to the eleventh grade students of SMAN 10 Pontianak in academic year 2015/2016. Four Corners is a strategy which allows students to think about a concept from four different perspectives of points of view. A quasi experimental design was implemented to achieve the purpose of this study. The measurement technique was employed in this research. The data collection instrument was written test. This research used the t-test formula to analyze the quantitative data obtained through written test. Furthermore, an analytic scoring rubric was developed to assess the students' writing in hortatory exposition text. The result of data analysis revealed the superiority of the experimental group to the control group. Hence, the four corners strategy was effective in helping the students to improve their writing hortatory exposition text.
\end{abstract}

\section{INTRODUCTION}

In School-Based Curriculum (KTSP), students of Senior High School are claimed not only to be able to speak but also to write various kinds of texts in English. There are 12 genres of texts that should be mastered by Senior High School students. They are narrative, recount, procedure, descriptive, news item, report, analytical exposition, hortatory exposition, spoof, explanation, discussion, and review text. One of the texts that eleventh grade students should master is hortatory exposition text. Hortatory exposition text is a type of spoken or written text that is intended to explain the listeners or readers that something should or should not happen or be done. 
A hortatory exposition text is a type of spoken or written text that is intended to explain the listeners or readers that something should or should not happen or be done (Priyana, 2008:161). In other words, this kind of text can be called as argumentation. Hortatory exposition text can be found in scientific books, journals, magazines, newspaper articles, academic speech or lecturers, and research report (Anderson, 1997:124). Hortatory expositions are popular among science, academic community and educated people.

The generic structure of hortatory exposition has three components: (1) Thesis, it is a statement or announcement of issue concern. (2) Arguments, they show reasons for concern that will lead to recommendation. (3) Recommendation, it includes the statement of what should or should not happen or be done based on the given arguments (Priyana, 2008:165). Hortatory exposition text also has the language features. There are (1) Focuses on generic human and non human participants, (2) It uses mental processes. Mental processes is used to state what the writer or speaker thinks or feels about something. For example: realize, feel etc, (3) It often needs material processes. It is used to state what happens, (4) It usually uses simple past tense and passive voice, (5) Enumeration is sometimes necessary to show the list of given arguments: firstly, secondly, and finally.

Based on the researcher's pre-research, it was found that most of the eleventh grade students of SMAN 10 Pontianak in Academic Year 2016/2017 had the problem in writing hortatory exposition text. Most of the students were difficult to write a hortatory exposition text because they should be able to see the topic of the text from two sides: pro and contra. They should also be able to write the arguments for each side. This thing arised the problem because the students tended to respond a certain issue emotively before knowing the facts and evidences. As a result, the students might feel difficult in writing the arguments from the side with which they might not agree.

Another problem arised when the teacher gave the topic in which the students were not familiar with. The students were difficult to develop their arguments because they did not have sufficient prior knowledge about the issue being discussed. They were also not given the opportunities to discuss their arguments with the other students. Whereas, in writing hortatory exposition text the students can support their point of view through survey results, interviews and research.

In accordance with the statement above, it was necessary for a teacher to do an innovation in teaching writing hortatory exposition text. One of the alternative ways is by implementing Four Corners strategy in teaching writing hortatory exposition text. Four Corners is a strategy which allows students to think about a concept from four different perspectives of points of view. The Four Corners is the strategy that is used to promote the equal participant among group; each participant has a turn to offer or his answer about the topic in the discussion. The purpose of Four Corners strategy is to provide contentrich topics in every unit, extensive opportunities to practice natural English, integrated skills, and a wide variety of engaging students' involvement. It is most suitably applied when students are lethargic and need some meaningful physical movement in order to refocus (Walqui, 2000:35). Furthermore, Guillaume (2007:20) stated that Four Corners strategy is a cooperative learning strategy that provides students with the opportunity to think about their opinions and then discuss those opinions with others. 
There was a previous research about the Four Corners strategy. Rahayu (2013) conducted a reseach about the use of Four Corners strategy in teaching speaking to senior high school students. Her study revealed that the Four Corners strategy was very useful in helping the students to enhance their speaking ability. It was proven by the increasing number of students participation in the process of teaching and learning speaking. Nevertheless, there had been few researches about teaching writing by using Four Corners strategy.

Regarding to the statement above, the researcher was encouraged to fill in the research gap and investigate the effectiveness of four corners strategy in teaching writing hortatory exposition text to the eleventh grade students of SMAN 10 Pontianak in academic year 2015/2016. Therefore, a quasi experimental design was utilized in this research. To sum up, there was a strong belief that this research would promote the four corners strategy as an effective strategy in teaching writing hortatory exposition text.

\section{METHOD}

Research design plays a crucial role in a research because the quality of research greatly depends on the design. In this research, the writer uses the form of quantitative approach to analyze the data. The quasi experimental research was selected to be implemented in this research. The researcher used quasi experimental research because all classes in SMAN 10 Pontianak had already set by the teachers based on the level of students' achievement. Therefore, the researcher could not randomly assign the research participants. Quasi experimental research defined by Ary, et al. (2010) is a type of evaluation which aims to determine whether a program or intervention has the intended effect on a study's participants. In this research, the researcher focussed on one form of quasi experimental studies that was a pre-post test design with a control group.

The procedure of quasi-experimental study which applied in this research was described in the following steps. The first step was the researcher applied the pre-test for both groups. After that, the researcher gave the treatments to the experimental group. The treatment was implemented in the process of teaching writing hortatory exposition text. In the process of teaching writing hortatory exposition text, the researcher used a four corners strategy as the treatment. The third step was the researcher applied the post test for both classes. The fourth step was comparing the result of pre-test and post-test to determine the students. Lastly, the research applied the appropriate statistical formula (ttest and effect size formula) to determine whether the students' writing in hortatory exposition text had improved significantly or not after implementing the four corners as a teaching strategy.

Because the fixed classrooms had been set by the teacher, it was impossible to randomize each indivual. Therefore, cluster sampling was applied in this research. Cluster sampling is a probability sampling procedure in which elements of the population are randomly selected in naturally occurring groupings or clusters (Thompson, 2002:27). When the clusters have been selected, all participants must take part in the research (Ary, et al., 2010). 
One way to randomize the sample is through a lottery using slips of paper (Ary, et al., 2010). Based on this recommendation, the researcher applied the procedure. The sample of experimental reserach was determined through the lottery in which four small folded pieces of paper with alphabetical codes from A to $\mathrm{F}$ representing all the classes in the eleventh grade were put into a small box. The box was closed and shaken afterwards. Finally, the box was opened and one piece of paper was picked and opened out of its folds. The first selected class (i.e. Class XI IPS 1) was experimentally assigned, whereas the second selected one (i.e. Class XI IPS 3) was the control group.

The researcher used measurement technique to measure the students' writing in hortatory exposition text. Since the data was obtained by using measurement technique, the relevant tool to collect the data was written test. It was used to assess students' writing performance. Students were asked to write a hortatory exposition text based on the topic given. The students' score from the test was used to find the mean score. In assessing the students' writing performance, the researcher provided the analytical scoring rubric so that the scoring would be more objective.

\section{RESULTS AND DISCUSSIONS}

From the result of the pre-test, it was found that both students in experimental and control group got difficulties in developing arguments 'for' and 'against' the issue. The students' difficulties in developing and strengthening ideas could be clearly seen when the students were given a topic by the researcher to write. The students were not able to strengthen their topic sentence by giving some examples and evidences. In addition, the students encountered difficulties in writing a thesis for hortatory exposition text. When they wrote the thesis, they were unable to provide the sufficient background information and outline the issue or topic being discussed. Therefore, both students in experimental and control group only got 18.24 and 18.40 for their content. Based on the scoring rubric that was used for assessing the students' writing, the arguments' scores of both groups were considered as "average".

This condition was in contrast with the students' score after implementing four corners strategy in the process of teaching writing hortatory exposition text. From the result of the post-test, it could be seen that the students' writing ability in writing hortatory text had been improved. The mean score of experimental group was 71.50 , the highest score was 95, and the lowest score was 65. Meanwhile, the students' mean score in control group was 50.70 , the highest score was 78 , and the lowest score was 50 .

After implementing the four corners strategy for teaching writing hortatory exposition text, the students in experimental group were able to develop and strengthen their arguments 'for' and 'against' the issue by providing some examples and evidences to support their statement of position. The students' argument score after implementing four corners strategy was 28.45 . The difference was about 5.17 if it was compared with the students'arguments score before implementing four corners strategy. Meanwhile, the students' arguments score in control group was 20.60. It showed that the score was lower than the pre-test's score. Based on the scoring rubric that was used for assessing the students' writing, the arguments' scores of experimental group was considered "good". Meanwhile, the students' arguments scores of control group is considered "average". 
Therefore, it could be concluded that there was an increase on the students' arguments score of experimental group from "average" to "good".

In addition, the students' post-test score of experimental group in writing a thesis and a recommendation aspect which were 24.07 and 19.70 also showing that their scores were increased after the researcher giving the treatment. The differences were about 2.83 and 1.23 if they were compared with the scores before implementing the opinion-gap activity. Meanwhile, the students' post-test score of control group in statement of position and recommendation aspect which were 19.53 and 18.60. In this case, the students' score of control group in thesis aspect was higher than the score in pre-test. However, the students' score of control group in recommendation aspech had decreased from 18.57 to 18.40 .

Based on the gathered data and related analysis, it was also found that the students were not familiar with hortatory exposition writing at the beginning of the study. The students only knew that the hortatory exposition text had a thesis, arguments and a recommendation, but they did not know how to develop arguments in hortatory exposition text. When the students were given the topic, they only could write the topic sentence. They were not able to strengthen their topic sentence by giving some arguments. During the process of teaching writing hortatory exposition text with their teacher, the students were only asked to create a hortatory exposition text without having practices how to develop arguments in that text. Hence, the major points of their hortatory exposition text were still lack of relevant arguments.

Those students were just able to write paragraphs and the performance of the pre-test hortatory exposition writing was just the same with the model of text they had learned in the previous writing courses taught by their teacher. In fact, they had developed their own text based on the concept that a text was a complete paragraph with an introductory paragraph, three or more body paragraphs, and a concluding paragraph. Meanwhile, in writing hortatory exposition text, the students are required to be able to create the thesis which can state the announcement of issue concern. They also must be able to write arguments which can show reasons for concern that will lead to recommendation. Another requirement that the students need to fulfill in order to write a good hortatory exposition text is that they must be able to write the statement of what should or should not happen or be done based on the given arguments.

The significant difference was found in the aspect of content especially in developing arguments in the hortatory exposition text. The students in experimental group were easily to develop their arguments after the writer implemented Four Corners strategy during the process of teaching writing hortatory exposition text. It happened because the writer asked the students to discuss with their group in order to make good arguments and recommendation. The writer gave the statement to the students and she asked the students to express their attitudes toward the topic given by using expression of attitudes that already taught by her.

Furthermore, another feature which could be referred to as a reason for the outperformance of the experimental group was the collaborative and interactive nature of the Four Corners strategy. In the experimental group, the students engaged in discussion and exchange of ideas. Therefore, the language use and language learning took place simultaneously. After discussing the material, each group was asked to present the report 
of their work in front of the classroom so that the other students could give feedback to them. The feedback given covered the arguments and recommendation that they already made with their group. It came from peers from other groups and sometimes from the teacher. The students in experimental group could use such a feedback both during the elaboration that is during the writing process and after that on their final products during the recommendation. Therefore, the feedback can be thought of as an advantage for this group while in the traditional class the student wrote their text individually.

In addition, at the beginning of the study the learning context was unnatural because the students were not given the opportunities to interact each other when they finished their task. The students only focused in writing without having any peer-review activity with the other students. The teacher had a dominant role in the process of teaching writing hortatory exposition text. The class situation was not alive and the students are uninteresting in writing activities. They only create a hortatory exposition text based on the topic given by the teacher. The students also did not have any opportunity to participate in writing since the teacher did not create such activity which could involve the students working collaboratively with their friends. As a result, the students were very passive. This learning condition is very contrast with the condition after implementing Four Corners strategy in the process of teaching writing hortatory exposition text.

From the result of t-test computation, it was found that t-obtained was 3.26. The researcher applied the significance level $(\alpha)$ of 0.05 with degree of freedom $(\mathrm{df})=\mathrm{N}_{1}+\mathrm{N}_{2}$ $-2=30+30-2=58$. Based on the table, for $(\alpha) 0.05$ with $(\mathrm{df})=58$, it was found that the $t_{\text {ratio }}=3.26>t_{\text {critical }}=(2.000)$. This finding indicated the significant difference result between pre-test and post-test. Therefore, the null hypothesis (Ho) was rejected and the alternative hypothesis (Ha) was accepted. In order to find out how significant the effectiveness of the treatment given to the experimental group, the researcher analyzed the effect of the treatment (Effect Size). From the result of the computation, it was found that the effect size of the treatment was 0.82. Based on the Cohen's criteria, it was qualified as "moderate". In conclusion, the use of four corners strategy was effective in teaching writing hortatory exposition text to the eleventh grade students of SMAN 10 Pontianak.

\section{CONCLUSION AND SUGGESTION}

Based on the result of the research, it could be concluded that Four Corners strategy was helpful for the students in the process of teaching and learning writing. The current study made it clear that Four Corners strategy was definitely more effective than traditional approach in teaching writing in general and in teaching writing mode like hortatory exposition text in particular. In fact, teaching writing to the eleventh grade students through Four Corners strategy had all of the advantages of the process approach to writing such as the focus on the processes involved in the preparation, introducing statement, discussion and reflection.

Four Corners strategy paid enough attention to all of the processes which are involved in producing a good hortatory exposition text. It fully considered such processes and helped students to brainstorm and develop more new ideas; it also activated their previous schemata and background knowledge, motivates the students and encourages them to write with concerning over specific language items. 
Related to the findings of the research, there are some suggestions: (1) to the academic institution. There is a need in the classroom activities to provide more activities to have writing task because it will encourage the students to write. The students need more opportunities to interact with their friends during the process of completing the writing task. Considering the potential of Four Corners strategy in improving students' writing skills, it is necessary for the teacher to learn about it. Therefore, the school can facilitate this by conducting workshops on Four Corners strategy, (2) to the English teachers. This study can be used as a reference for the English teachers in improving the quality of teaching by applying the suitable technique toward improving the students' writing ability. Besides, the teachers can apply Four Corners stratey in the other aspect of English skills like reading, listening, or speaking. The research findings are expected to give insight to the teaching writing, (3) to other writers. This research is also expected to be beneficial to other writers particularly those who are interested in conducting a similar research by implementing four corners strategy to other English skills.

\section{REFERENCES}

Anderson, M. and Anderson, K. (1997). Text Types in English. Macmillan: MacMillan Education Australia PTY LTD.

Ary, D., Lucy, C., Jacobs, \& Sorensen. (2010). Introduction to Research in Education. Canada: Wadswort, Cencage Learning.

Belcher, D. and Liu, J. (ed). (2004). Genre and Second Language Writing. Michigan: The University of Michigan Press.

Blerkom, M.L.V. (2009). Measurement and Statistics for Teachers. New York: Routledge.

Cohen, L. et al. (2007). Research Methods in Education. Sixth Edition. London and New York: Routledge-Falmer is an imprint of the Taylor and Francis Group.

Crawford, Matheus, Samuel and Makinster, J. (2005). Teaching and Learning Strategies for the Thinking Classroom. New York: The International Debate Education Association.

Creswell, J. W. (2012). Educational Research: Planning, Conducting, and Evaluating Quantitative and Qualitative Research $\left(4^{\text {th }} e d\right)$. Boston: Pearson Education.

Davis, K. W. (2004). Manage Your Writing. Indiana Polis: Komei Inc.

Depdiknas. (2006). Kurikulum Tingkat Satuan Pendidikan (KTSP). Jakarta: Depdiknas.

Gay, L. R., Mills, G. E., \& Airasian, P. W. (2011). Educational Research: Competencies for Analysis and Applications (Tenth ed.). Upper Saddle River: Pearson Education. 
Ghaith, G. (2002). Writing. Beirut: American University of Beirut.

Grenville, K. (2001). Writing From Start To Finish A Six-Step Guide. Australia: Griffin Press South.

Guillaume, M. A., Yopp, Helen, R., \& Yopp, Kay, H. (2007). 50 Strategies for Active Teaching._Upper Saddle River, New Jersey: Pearson Education, Inc.

Harmer, J. (2004). How to Teach Writing. London: Longman. Hill Book Company.

Heaton, J. B. (1975). Writing English Language Test. London: Longman.

Johnson, A. P. (2008). Teaching Reading and Writing; A Guidebook for Tutoring and Remediating Students. Maryland: Rowman \& Littlefield Education.

Lodigo, M., Spaulding, D., \& Voegtle, K. (2010). Methods in Educational Research. San Fransisco: Jossey-Bass.

Marzano, R.J. (2005). A Handbook for Classroom Management that Works. United States: ASCD.

McCaskill. (1998). Grammar, Punctuation and Capitalization. A Handbook for Technical Writers and Editors. Hamptonm Virginia: Langley Research Center.

Meyers, A. (2005). Gateaways to Academic Writing: Effective Sentences, Paragraphs and Essays. United States: Longman.

Nation, I.S.P. (2009). Teaching ESL/EFL Reading and Writing. New York: Routledge.

Priyana, J. (2008). Interlanguage: English for Senior High School Students XII Science and Social Study Program. Jakarta: Pusat Perbukuan, Departemen Pendidikan Nasional.

Rumsey, D. (2010). Statistic Essentials For Dummies. Indiana: Wiley Publishing, Inc.

Samsudi. (2008). Statistika. Semarang: Fakultas Teknik Universitas Negeri Semarang.

Sudarwati and Grace, E. (2007). Look Ahead: An English Course for Senior High School Students Year XI, Science and Social Study Program. Jakarta: Erlangga.

Thompson, S. K. (2002). Sampling. New York: Wiley \& Sons.

Walqui, A. (2000). Contextual Factors in Second Language Acquisition. Eric Digest. Washington DC: ERIC Cleaninghouse on Languages and Linguistics. section "The Learning Process", para. 2.

Weigle, S. C. (2002). Assessing writing. Cambridge, UK: Cambridge University Press. 
Westat, J.F. (2002). The 2002 User Friendly Handbook for Project Evaluation. The National Science Foundation: Division of Research, Evaluation and Communication. 